\title{
Sistem Monitoring Pemakaian Daya Listrik dan Kontrol Peralatan Elektronik Berbasis PC Server
}

\author{
Haryadi Amran Darwito, Akuwan Saleh \\ Jurusan Teknik Telekomunikasi, Politeknik Elektronika Negeri Surabaya \\ Institut Teknologi Sepuluh Nopember (ITS), Surabaya, Indonesia \\ Kampus ITS Keputih Sukolilo, Surabaya 60111 \\ Telp. +62 (31) $5947280 \quad$ Fax +62 (31) 5946114 \\ E-mail: amran@eepis-its.edu, akuwan@eepis-its.edu
}

\begin{abstract}
ABSTRAK
Mengingat terbatasnya persediaan sumber energi listrik yang ada, efisiensi penggunaannya harus dilakukan. Selain itu, penggunaan energi listrik yang terkendali sangat menguntungkan karena beban biaya akan lebih rendah.

Sistem monitoring dan kontrol penggunaan energi listrik pada paper ini merupakan salah satu alternatif untuk melakukan penghematan energi listrik tersebut. Bagian hardware dari sistem ini adalah KWH Meter, sensor optocoupler, rangkaian kontrol menggunakan mikrokontroler, dan driver relay. Kenaikan beban daya dan lama penggunaan listrik dapat diketahui, karena piringan KWH Meter dipasang sensor optocoupler untuk menghitung jumlah putaran piringan KWH meter.

Pembuatan software menggunakan pemrograman Visual Basic 6.0 untuk mengetahui rincian perhitungan biaya yang dibebankan dan mengatur pemakaian daya listrik melalui komputer yang difungsikan sebagai server, dimana peralatan elektronik dapat di aktivasi (On/Off) secara manual atau otomatis mengunakan setting time.

Hasil yang telah diperoleh dari sistem ini berupa informasi penunjukan angka pada KWH Meter dengan beban daya minimal 140 watt, kondisi peralatan On/Off berdasarkan setting time untuk mengontrol pemakain daya listrik, informasi beban biaya melalui PC server maupun secara jarak jauh menggunakan Internet dan Handphone yang support GPRS.
\end{abstract}

\section{PENDAHULUAN}

Seiring perkembangan teknologi saat ini banyak sekali dibuat peralatan elektronik yang mendukung kegiatan manusia sehari-hari. Akan tetapi user hanya mengerti cara menggunakannya tanpa mengetahui besar biaya pemakaian listrik yang digunakan pada peralatan - peralatan elektronik tersebut, bahkan user sering lupa untuk mematikan peralatan elektronik sehingga daya listrik menjadi besar, hal ini menimbulkan kerugian yang besar bila terjadi terus menerus, pemakaian listrik yang besar mengakibatkan beban biaya yang harus dikeluarkan juga semakin besar. Oleh karena itu perlu dibuat suatu sistem informasi yang dapat memudahkan dalam pencatatan KWH Meter, mengontrol $(\mathrm{On} / \mathrm{Off})$ peralatan-peralatan elektronik tersebut baik secara manual ataupun otomatis dan mengetahui beban biaya melalui komputer server maupun secara jarak jauh menggunakan Internet dan Handphone yang support GPRS.

Pembuatan pada sistem ini terdiri dari pembuatan hardware yaitu men-instalasi KWH Meter dengan jaringan listrik, pemasangan sensor optocoupler pada piringan KWH Meter, pembuatan rangkaian catu daya, pembuatan rangkaian mikrokontroler, pembuatan driver relay yang berfungsi sebagai pengaktif relay dan pembuatan rangkaian sensor optocoupler dengan tujuan agar kenaikan beban daya dan lama penggunaan listrik dapat diketahui, karena piringan KWH Meter telah terpasang sensor optocoupler untuk menghitung jumlah putaran piringan KWH meter. KWH meter yang digunakan golongan R1-1300 untuk daya 1300 watt termasuk TDL atau tarif daya listrik blok I (0-20 KWH) dengan tarip 385/KWH.

Pembuatan software menggunakan pemrograman Visual Basic 6.0 untuk mengetahui rincian perhitungan biaya yang dibebankan dan mengatur pemakaian daya listrik melalui komputer yang difungsikan sebagai server, dimana peralatan elektronik dapat di aktivasi $(O n / O f f)$ secara manual atau otomatis mengunakan setting time. Peralatan yang dikontrol pada pengujian sistem ini hanya 8 peralatan elektronik. Komunikasi antara mikrokontroler sebagai media kontrol peralatan dengan komputer server menggunakan komunikasi serial. Dari pengujian dan implementasi sistem ini telah diperoleh hasil bahwa kontrol alat secara manual atau otomatis menyebabkan efisiensi listrik dan estimasi beban biaya terhadap penggunaan listrik 
National Conference: Design and Application of Technology 2009

yang berlebihan. Dengan demikian sistem yang telah dibuat dapat membantu menghemat energi listrik sebagai estimasi beban biaya pemakaian daya listrik serta dapat memudahkan pengontrolan peralatan elektronik melalui PC server maupun secara jarak jauh menggunakan Internet dan Handphone.

\section{LANDASAN TEORI}

Pada bagian ini akan dijelaskan teori-teori yang berhubungan dengan peralatan yang telah dibuat dan terpakai pada sistem yang terdiri dari KWH meter, rangkaian sensor optocoupler, rangkaian driver relay, perhitungan beban daya dan biaya listrik berdasarkan TDL golongan RI-1300.

\subsection{KWH Meter}

KWH meter [1],[2] merupakan alat untuk mengukur dan menampilkan pemakaian daya listrik. Prinsip kerja KWH meter berdasarkan bekerjanya induksi magnetis oleh medan magnet. Berfungsi sebagai penghitung besarnya energi listrik yang terpakai ke dalam bentuk jumlah putaran, sehingga semakin banyak beban listrik yang dipakai maka semakin banyak pula jumlah putaran yang terjadi dalam selang waktu tertentu. KWH meter memiliki empat konektor, yang masing-masing konektor memiliki fungsi yang berbeda-beda.

Langkah pertama dalam instalasi KWH Meter adalah harus mengetahui fungsi dari konektor konektor yang ada dalam KWH meter. Dalam Gambar 2 diasumsikan keempat konektor itu adalah A,B,C, dan D. Jalur fasa dari PLN disambungkan pada konektor A, jalur nol dari PLN kita pasangkan pada konektor C. Untuk konektor B dan D digunakan sebagai output dari KWH Meter, dimana B sebagai fasa dan D sebagai nol (Ground).

Dalam pemasangannya seperti pada gambar 1 tidak boleh ada kesalahan, karena konektor-konektor tersebut tersambung dengan lilitan-lilitan yang terdapat dalam KWH meter yang berfungsi sebagai penginduksi lempengan, sehingga lempengan akan berputar kearah yang benar. Keluaran listrik AC dari KWH meter dilewatkan MCB (Mini Circuit Breaker) sebelum menuju ke beban. MCB tersebut berfungsi sebagai pemutus hubungan antara beban dan KWH meter bila terjadi hubungan pendek pada listrik, dengan demikian akan memperkecil terjadinya kebakaran yang disebabkan oleh hubungan pendek dari jaringan listrik yang telah dipasang.

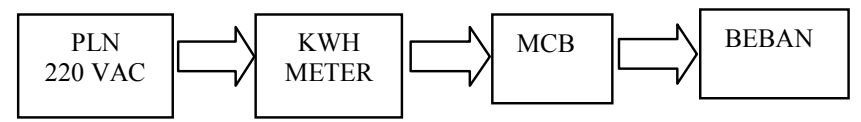

Gambar 1. Blok Diagram Pemasangan KWH Meter

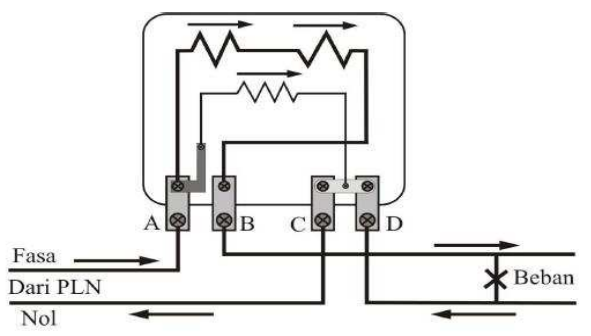

Gambar 2. Instalasi KWH Meter Satu Fasa

\subsection{Rangkaian Sensor Optocoupler}

Sensor ini terdiri atas LED infra merah dan fototransistor. Cara kerja sensor yaitu ketika cahaya infra merah tidak terhalang masuk ke fototransistor maka fototransistor akan aktif dan meneruskan arus dari emitter ke collector, begitu juga sebaliknya. Rangkaian sensor berfungsi sebagai penghitung putaran piringan KWH meter. Dalam rangkaian ini supaya dapat mengirimkan data ke komputer diperlukan sebuah alat koneksi antara keduanya. Pada rangkaian digunakan komunikasi serial antara mikrokontroler dengan komputer [3],[4]. Dengan software yang telah dibuat, maka jumlah putaran tersebut dapat dikonversikan menjadi beban daya dan biaya, sehingga pemakaian daya listrik dapat termonitoring dari komputer. 


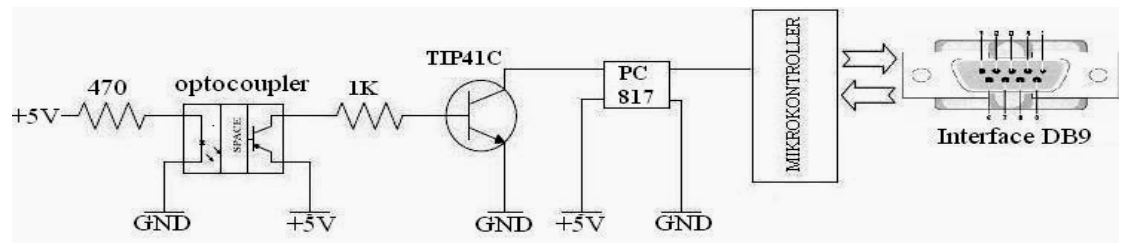

Gambar 3. Rangkaian Sensor Optocoupler

\subsection{Rangkaian Driver Relay}

Rangkaian driver seperti ditunjukan pada gambar 4 menggunakan transistor TIP41C yang fungsinya sama dengan transistor 2N3906 yaitu sebagai transistor switching [5], yang membedakan adalah transistor TIP41C ini bertipe NPN jadi arus akan diteruskan dari collector menuju emitter, dan transistor ini akan aktif bila pada kaki basisnya diberi input tegangan sebesar $5 \mathrm{~V}$ yang berasal dari keluaran kaki collector transistor 2N3906 tipe PNP sebelunnya. Pada transistor TIP41C juga diberi input tegangan pada kaki collector sebesar $24 \mathrm{~V}$ yang digunakan untuk mengaktifkan relay 24 volt. Jadi rangkaian akan aktif, bila pada kaki basis transistor TIP41C mendapat input $5 \mathrm{~V}$, sehingga tegangan $24 \mathrm{~V}$ dari kaki collector dapat diteruskan menuju kaki emitter dan relay $24 \mathrm{~V}$ akan aktif.

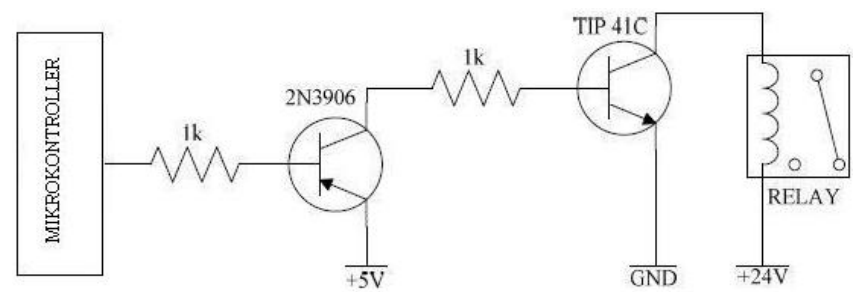

Gambar 4. Rangkaian Driver Relay

\subsection{Perhitungan Beban Daya Dan Biaya Listrik}

Setiap Tarif Dasar Listrik (TDL) dikelompokkan sesuai dengan golongannya [1]. KWH meter yang digunakan merupakan golongan R1-1300. TDL dari golongan tersebut dapat dilihat pada Tabel 1.

Tabel 1. TDL Golongan R1-1300

\begin{tabular}{|c|l|c|}
\hline No & \multicolumn{1}{|c|}{ Item } & Perhitungan \\
\hline 1 & Bea beban & $(1300 / 1000) \times$ Rp. 30.100,- \\
2 & Blok I $: 0-20 \mathrm{KWH}$ & $20 \mathrm{KWH} \times$ Rp. 385,- \\
3 & Blok II $: 21-60 \mathrm{KWH}$ & $40 \mathrm{KWH} \times$ Rp. 445,- \\
4 & Blok III $:>60 \mathrm{KWH}$ & $>60 \mathrm{KWH} \times$ Rp. 495,- \\
\hline
\end{tabular}

Perhitungan beban biaya dapat dilihat pada persamaan di bawah ini :

$$
\text { Konsumsi listrik }=\frac{\text { Jumlah Putaran Piringan }}{\text { Karakterisik Tipe KWH }}
$$

Karakteristik Tipe $\mathrm{KWH}=2500$ putaran

$$
\text { Beban biaya }+ \text { Bea beban }=(\text { konsumsi listrik } \times \text { TDL })+R p .39130-
$$

\section{METODOLOGI}

Dalam pembuatan sistem dibutuhkan pembuatan hardware dan software. Penjelasan secara umum yaitu piringan KWH meter dimodifikasi dengan penambahan sensor optocoupler yang berfungsi sebagai pendeteksi jumlah putaran piringan. Mikrokontroler sebagai pusat pengolah data dan pengontrol alat. 
Mikrokontroler dan interface DB9 merupakan alat koneksi untuk mengirimkan data ke PC sehingga diketahui beban daya dan biaya.

\subsection{Perancangan Sistem}

Pada gambar 5 merupakan blok diagram dan gambar 6 rancangan keseluruhan dari sistem monitoring dan kontrol peralatan elektronik yang telah dibuat.

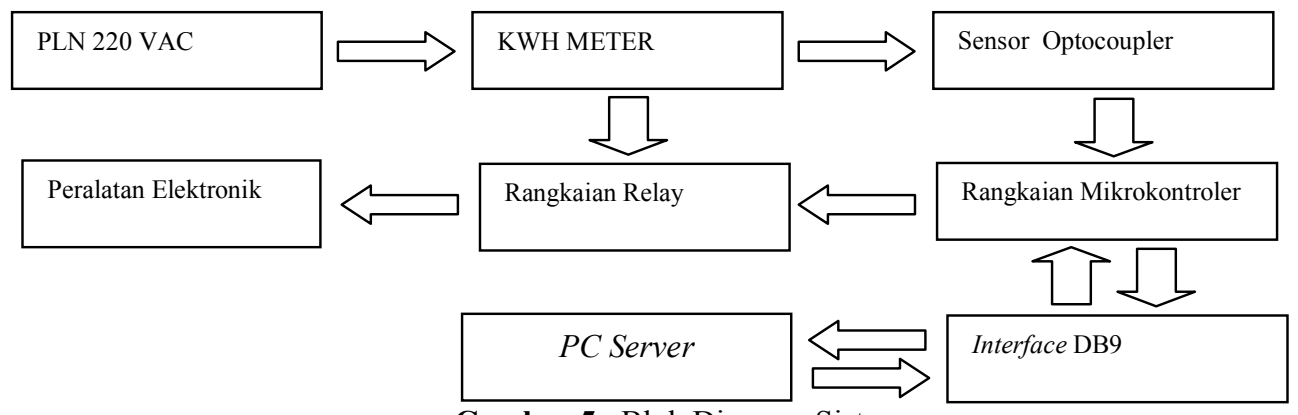

Gambar 5. Blok Diagram Sistem

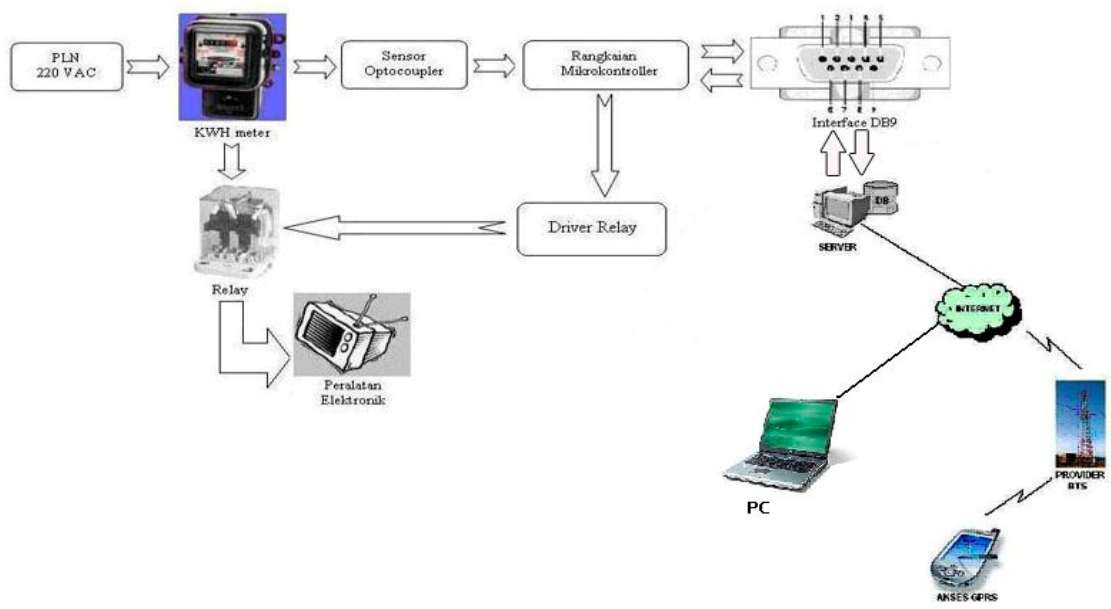

Gambar 6. Rancangan Keseluruhan Sistem

\subsection{Perancangan dan Pembuatan Perangkat Keras}

Perancangan dan pembuatan hardware antara lain pembuatan rangkaian catu daya, mikrokontroler, driver relay, pemasangan sensor optocoupler pada piringan KWH Meter. Hardware yang telah dibuat dapat dilihat pada gambar 7 .

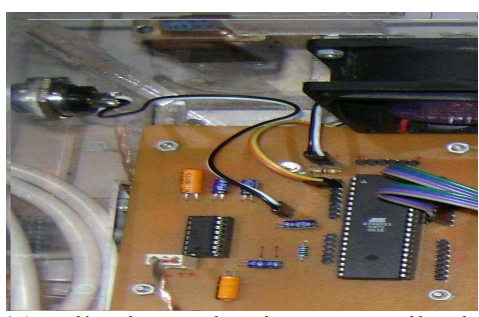

(a) Mikrokontroler dan Komunikasi Serial

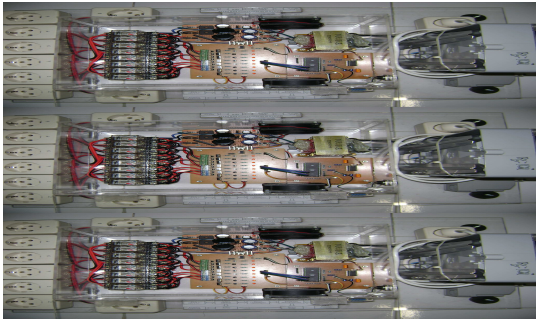

(b) Rangkaian Kontrol Peralatan Elektronik

Gambar 7. Sistem Kontrol Peralatan Elektronik 


\subsection{Perancangan Dan Pembuatan Perangkat Lunak}

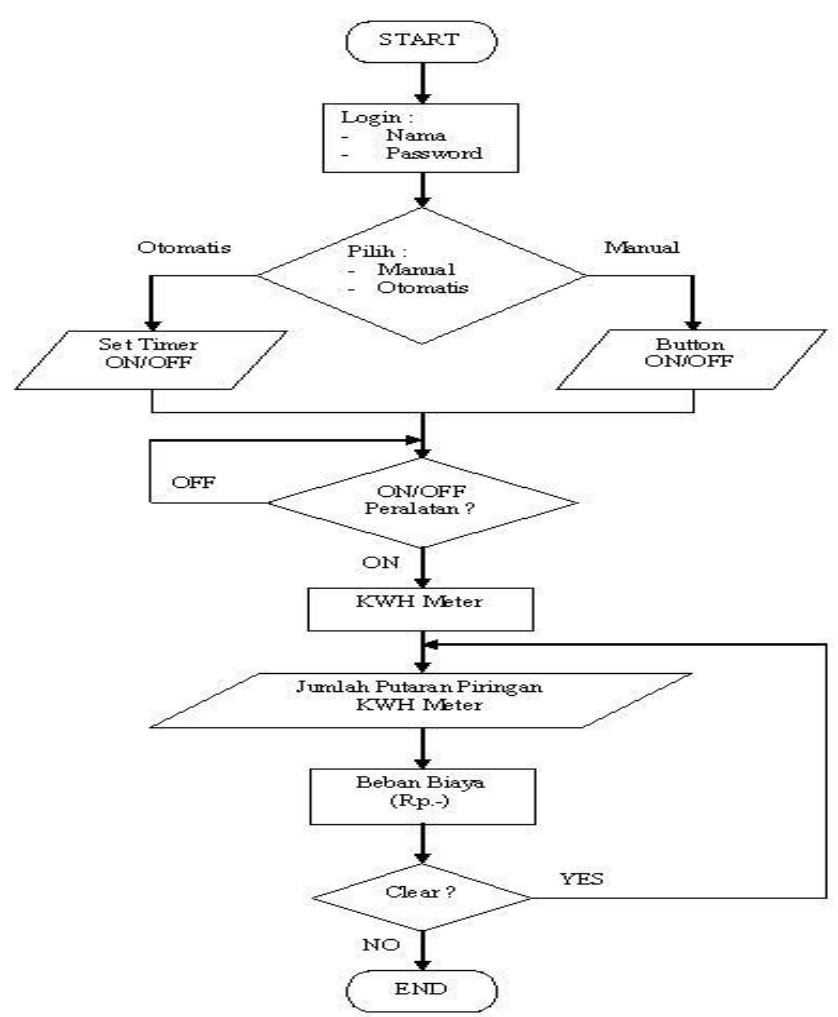

Gambar 8. Flowchart Sistem Kontrol Peralatan Elektronik

Penjelasan dari flowchart pada gambar 8 adalah saat sistem dieksekusi, user akan menemui form login, pada form ini harus mengisi nama dan password yang telah terdaftar bila ingin masuk ke sistem kontrol dan monitoring. Setelah proses login berhasil, akan terlihat tampilan sistem dan terdapat dua pilihan kontrol manual atau otomatis. Untuk kontrol secara manual, langsung pilih alat yang ingin dikontrol. Untuk kontrol secara otomatis, set timer sesuai kebutuhan. Peralatan on maka KWH meter akan bekerja dan piringannya akan berputar. Jumlah putaran piringan tersebut akan dikonversi menjadi beban daya sehingga beban biaya dapat diketahui. Tampilan dari menu utama dapat dilihat pada Gambar 9. Pada menu utama terdapat dua menu yaitu monitoring dan kontrol, sehingga dapat dipantau antara lain kondisi sensor, status alat, jumlah putaran piringan KWH meter, beban daya dan beban biaya.

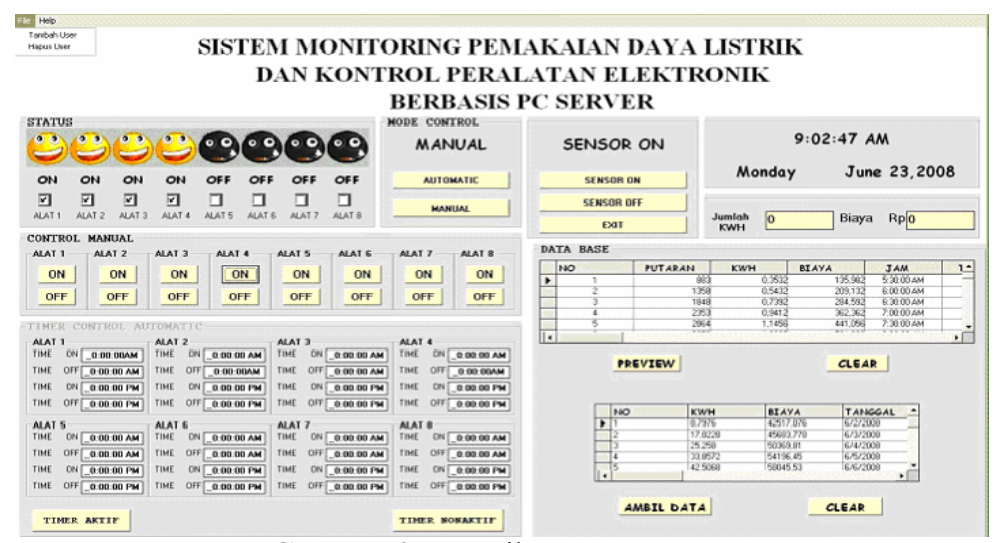

Gambar 9. Tampilan Menu Utama

Disamping menu utama terdapat pula menu penunjang terdiri dari beberapa form yaitu form login, form tambah user, form hapus user dan form petunjuk. 


\subsubsection{Pembuatan Database pada server}

Pada PC server dilakukan pembuatan menu Software database yang digunakan adalah database MySQL yang telah terinstal bersama apachetriad [6],[7]. Untuk database pembuatan sistem ini diperlukan 3 tabel yaitu user, status peralatan, dan KWH Meter.

\subsubsection{Pembuatan Web}

Tahap awal yang dilakukan adalah membuat program menggunakan notepad [8], kemudian mendesain dan membuat web dengan mengunakan software Dreamweaver $M X$ dan Photoshop.

\subsubsection{Pembuatan Software Pada HP}

Pembuatan program pada telepon genggam menggunakan bahasa pemrograman J2ME. Program ini akan dibuat dengan melihat emulator, dan di-download ke telepon genggam [9]. Untuk koneksi antara telepon genggam dengan server, digunakan bahasa pemrograman PHP. Program PHP script tersebut dipanggil oleh program J2ME dengan syntax sebagai berikut:

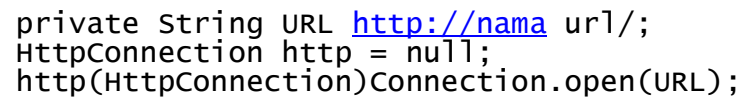

\section{PENGUJIAN DAN ANALISA}

Pengujian dilakukan untuk mengetahui performansi dari sistem yang dibuat. Ketepatan eksekusi antara software dengan hardware yang dibuat sangat diharapkan dalam proses ini. Peralatan yang digunakan pada pengujian ini adalah $P C$ (Personal Computer), kabel penghubung (serial port), dan peralatan elektronik 8 buah ( Kulkas, Magic Com, Rice Cooker, Hiasan Ruang Tamu (Air Terjun Mini), TV di Kamar, TV di Ruang Keluarga, Kipas Angin Kamar, dan Kipas Angin Ruang Keluarga.

\subsection{Pengujian Instalasi KWH Meter}

Pengujian ini bertujuan untuk mengetahui kinerja dari KWH meter. Cara pengujian yaitu diberikan beban daya bervariasi dan diamati putaran piringan harus diarah yang benar.

Tabel 2. Data Pengujian Instalasi KWH Meter

\begin{tabular}{|c|c|c|}
\hline No & Beban (Watt) & Kondisi Piringan \\
\hline 1 & 40 & Tidak bergerak \\
\hline 2 & 80 & Tidak bergerak \\
\hline 3 & 100 & Tidak bergerak \\
\hline 4 & 140 & Berputar (Pelan) \\
\hline 5 & 300 & Berputar (Cepat) \\
\hline
\end{tabular}

Pada tabel di atas terlihat piringan KWH Meter mulai berputar pelan dengan beban 140 watt. Piringan berputar karena mendapat cukup beban dan penunjukan angka pada KWH meter terus bertambah.

\subsection{Pengujian Sistem Kontrol}

Pengujian sistem kontrol secara manual maupun otomatis masing-masing dilakukan melalui PC dan internet seperti pada tabel 3 dan tabel 4. Pengujian koneksi antara $J 2 M E$ pada $H P$ yang menggunakan GPRS dan PHP pada Web dengan hardware sistem yang telah dibuat. 
Tabel 3. Pengujian Kontrol Manual

\begin{tabular}{|c|c|c|c|c|}
\hline No & Peralatan Elektronik & $\begin{array}{c}\text { Perintah Dikirim } \\
\text { Via Internet }\end{array}$ & Perintah Diterima PC & Status Alat \\
\hline 1 & Alat 1 & ON & ON & Nyala \\
\hline 2 & Alat 2 & OFF & OFF & Mati \\
\hline 3 & Alat 3 & OFF & ON & Nyala \\
\hline 4 & Alat 4 & ON & ON & Nyala \\
\hline 5 & Alat 5 & ON & OFF & Mati \\
\hline 6 & Alat 6 & OFF & OFF & Mati \\
\hline 7 & Alat 7 & OFF & ON & Nyala \\
\hline 8 & Alat 8 & ON & & \\
\hline
\end{tabular}

Tabel 4. Pengujian Kontrol Otomatis

\begin{tabular}{|c|c|c|c|c|c|}
\hline No & $\begin{array}{c}\text { Peralatan } \\
\text { Elektronik }\end{array}$ & $\begin{array}{c}\text { Waktu yang } \\
\text { Dikirim }\end{array}$ & $\begin{array}{c}\text { Perintah yang } \\
\text { Dikirim }\end{array}$ & $\begin{array}{c}\text { Perintah Diterima } \\
\text { PC }\end{array}$ & $\begin{array}{c}\text { Status } \\
\text { Alat }\end{array}$ \\
\hline 1 & Alat 1 & 0700 & ON & ON & Nyala \\
\hline 2 & Alat 1 & (kosong) & OFF & ON & Nyala \\
\hline 3 & Alat 1 & $07: 00$ & OFF & ON & Nyala \\
\hline 4 & Alat 2 & 0800 & OFF & OFF & Mati \\
\hline 5 & Alat 3 & 0900 & OFF & ON & Nyala \\
\hline 6 & Alat 4 & 1000 & ON & ON & Nyala \\
\hline 7 & Alat 5 & 1100 & ON & OFF & Mati \\
\hline 8 & Alat 6 & 1200 & OFF & OFF & Mati \\
\hline 9 & Alat 7 & 1300 & OFF & ON & Nyala \\
\hline 10 & Alat 8 & 1400 & ON & & \\
\hline
\end{tabular}

Kontrol alat secara otomatis telah berhasil sesuai perencanaan. Dari tabel 4 (nomer 2 dan 3) dapat dilihat bahwa jika user tidak mengisi waktu, atau memasukkan waktu yang tidak sesuai format maka system tidak akan jalan. Alat elektronik dapat on/off sesuai dengan timer yang telah ditentukan. Berhasilnya kontrol alat secara manual atau otomatis menyebabkan efisiensi listrik dan estimasi beban biaya terhadap penggunaan listrik yang berlebihan.

\subsection{Pengujian Kerja Sensor}

Pengujian sensor dilakukan selama waktu tertentu. Dari hasil pengujian pada Tabel 5. dapat dianalisa bahwa piringan mulai berputar dengan beban minimal sebesar 140 watt. Software dapat menampilkan pembacaan data dari sensor berupa jumlah putaran piringan.

Tabel 5. Pengujian Kerja Sensor

\begin{tabular}{|c|c|c|c|c|}
\hline No & Beban (Watt) & Waktu (s) & Jumlah Putaran Piringan & Biaya (Rp) \\
\hline 1 & 40 & 300 & 0 & 0 \\
\hline 2 & 80 & 300 & 0 & 0 \\
\hline 3 & 100 & 300 & 0 & 0 \\
\hline 4 & 140 & 300 & 57 & 8,778 \\
\hline 5 & 300 & 300 & 80 & 12,32 \\
\hline
\end{tabular}

\subsection{Pengujian Perhitungan Beban Daya Dan Biaya Listrik}

Selanjutnya data putaran dari pembacaan sensor dikonversi melalui perhitungan sehingga didapatkan beban biaya listrik seperti ditunjukan pada tabel 6 . 
Tabel 6. Tampilan Pada Database

\begin{tabular}{|c|c|c|c|c|}
\hline No & Putaran & KWH & Biaya + Bea Beban & Tanggal \\
\hline 1 & 21994 & 8,7976 & 42517,076 & 02 -Jun-08 \\
\hline 2 & 42557 & 17,0228 & 45683,778 & $03-J u n-08$ \\
\hline 3 & 63145 & 25,258 & 50369,81 & $04-J u n-08$ \\
\hline 4 & 84643 & 33,8572 & 54196,45 & $05-J u n-08$ \\
\hline 5 & 106267 & 42,5068 & 58045,53 & $06-J u n-08$ \\
\hline 6 & 128651 & 51,4604 & 62029,88 & $07-J u n-08$ \\
\hline 7 & 147932 & 59,1728 & 65461,90 & 08 -Jun-08 \\
\hline
\end{tabular}

Berdasarkan tabel 1. TDL Golongan R1-1300 dan persamaan (1), (2), dapat dilakukan perhitungan sebagai berikut:

$$
\begin{aligned}
& \text { Konsumsi listrik }=\frac{21994}{2500}=87976 K W H \\
& \text { Beban biaya }+ \text { Bea beban }=(87979 \times \text { Rp. } 385)+R p .39130=R p .42517,076
\end{aligned}
$$

Dari pengujian yang telah dilakukan bila dibandingkan didapatkan hasil yang sama antara perhitungan secara manual dengan database pada software (tabel 6).

\section{KESIMPULAN} bahwa :

Dari hasil pengujian sistem kontrol peralatan secara otomatis dan manual dapat ditarik kesimpulan

1. Dari pengambilan data selama 7 hari diperoleh besar daya yang dipakai sebanding dengan jumlah putaran piringan KWH dan besar biaya listrik.

2. Sistem kontrol otomatis dengan pengaturan waktu (setting time) nyala peralatan elektronik dapat menghidari pemakaian alat yang berlebihan sehingga dapat menekan beban biaya listrik.

3. Pemakai dapat mengetahui informasi peralatan on/off, waktu aktif, beban biaya listrik setiap hari secara langsung pada PC server maupun dari jarak jauh.

4. Informasi penunjukan angka pada KWH Meter dengan beban daya minimal 140 watt, karena pada beban ini mendapat daya yang cukup untuk memutar piringan KWH meter.

\section{REFERENSI}

[1]. Ichwannudin, M. (2007). Pencatatan Meter PLN Menggunakan Image Processing, Surabaya, Proyek Akhir Politeknik Elektronika Negeri ITS.

[2]. Ton Sejati Utomo, Artikel Alat Ukur Listrik KWH Meter, Surabaya, 2007

[3]. Budiharto, W. (2004). Interfacing Komputer dan Mikrokontroler, Jakarta, PT Elex Media Komputindo.

[4]. $\quad$ Prasetia, R dan Widodo, CE. (2004). Teori dan Praktek Interfacing Port Paralel dan Port Serial Komputer dengan Visual basic 6.0, Yogyakarta, ANDI Yogyakarta.

[5]. Malvino, Albert paul. Prinsip-prinsip elektronika. Salemba teknika. Jakarta. 2003.

[6]. Winemiller, Eric et al. (1998). Visual Basic 6 Database How - To, USA, Sams Publishing, Indianapolis.

[7]. Zen Hadi, M. S, Database MySQL, 20085 April http://lecturer.eepisits.edu/ zenhadi/kuliah/internet

[8]. Zen Hadi, M. S, WEB Programming: PHP(1), 20085 April http://lecturer.eepisits.edu/ zenhadi/kuliah/internet

[9]. Presented by developerWorks, your source for great tutorials, ibm.com/developerWorks. J2ME: Step by step. 20085 Mei http://www.digilife.be/quickreferences/pt/j2me step by step.pdf. 